\title{
Culturally-Responsive Strategies for Resolving Social Conflict in Rural Community
}

\author{
Alfitri \\ University of Sriwijaya, Indonesia \\ Email:al_fitri2002@yahoo.com \\ Mohd Mahzan Awang \\ Abdul Razaq Ahmad \\ Universiti Kebangsaan Malaysia, Malaysia
}

Doi:10.5901/mjss.2014.v5n20p2267

\begin{abstract}
Conflict is an inherent reality and always exist in the community. The aim of this study is to explore the cultural aspects which contribute to the regularity and peace in a society, and the mechanisms in the form of conflict resolution models to resolve conflicts in the communities that rely on the value of local wisdom. The methodology of the research is a qualitative approach. Data collection was conducted by using in-depth interviews. Observations were done to look at the ways how people resolve conflicts by conducting and participating in traditional ceremonies. Data were analyzed through a coding process by three researchers in the form of a discussion to formulate the findings and conclusions of the study. The application of the model was agreed upon by several experts and specialists after a process of discussion. The results of the study showed that the value of conflict resolution through local wisdom in traditional local community outside of airports in Indonesia, particularly in Talang Sejumput area is able to maintain peaceful conditions in the community in a sustainable manner. The application of conflict resolution models in rural communities can be used as a reference in the resolution of conflicts in the societies with differences in culture and structure by adapting to the local values and cultural conditions of the local community.
\end{abstract}

Keywords: Social, Conflict, Resolution, Local Wisdom, Rural Community, Traditional Society

\section{Introduction}

Conflict is a reality that has always existed in a society. Conflict is a normal reality and inevitability as long as there are interaction and collaboration between people. The form and characteristics of the conflict are very diverse and unique depending on the motives, setting, actors and issues. The dimensions of the reality of conflict is sometimes horizontal and sometimes vertical. Today many approaches are often used for the resolution of the conflict, for example a solution model based on the source of conflict, Boulding models, position of interest and requirements model, third party intervention models and many other models. Any conflict which has been handled that cannot be resolved has the potential to be violent. A commonly used conflict resolution is usually sourced from an approach to conflict that considers a conflict as a reality that is not unusual which should be eliminated. For example, a formal legal approach that is often done by the government through litigation to resolve structural conflicts is a method that sometimes backfire that the conflict is caused to be worse. The results of a study (Abolmaali, 2014) showed that avoidant and anxious styles have a significant and positive relationship with social dysfunctional problem solving, and has a significant and negative relationship with social problem-solving skills that are functional. This study shows that the resolution of social conflicts is one of the serious social problems, so the solution must be sought in accordance with the conditions of the community. The results of another study (Celina Del Felice, 2008) showed that police response in dealing with a problem in a violent manner is not effective at all, whereas it even contributes to the increase of tension and polarization, while the coping strategies of cultural and structural violence is more suitable for the type of urban social conflict.

While the absence of other means which are adequately tested to find the best solution to manage conflict, the rich diversity of Indonesian culture which contains many values of local wisdom, in fact, has long existed in managing the public in order to create a peace living. Some of the valuable local wisdom are: The Three-legged Stove (Dalihan Natolu/ Tungku yang Berkaki Tiga) in Tapanuli, Betang House (Rumah Betang/ Rumah Panjang Adat Suku Dayak Ngaju) in Central Kalimantan, Working Together Among Brothers and Relatives (Menyama Braya/Gotong Royong Saudara 
Kerabat) in Bali, Exchanging Gifts and Mutually Visiting (Saling Jot dan Saling Pelarangin/Saling Memberi, Menerima dan Menziarahi) in NTB, I Say Yes to You, You Say Yes to Me (Siro yo Ingsun, Ingsun yo Siro/ Anda Ya Saya, Saya Ya Anda) in East Java, Be careful as long as it is done (Alon-alon Asal Kelakon / Berhati-hati asalkan dibuat) in Central Java and DI Yogyakarta, Equally Stacking Betel Leaves (Basusun Sirih / Menyusun Sirih dengan Rapi) in Malay/Sumatera, Peradilan Adat Clan Selupu Lebong in Bengkulu, Flour Bidding (Tepung Tawar) in South Sumatra.

In South Sumatera, the term "Bidding Flour" (Tepung Tawar) exists as a method of conflict resolution, which was derived from a manuscript of Customary Law Act "Totrrent of Light" (Simbur Cahaya), which had been used for several centuries in the past, and is still applied to date in several local communities. Talang Sejumput community is one of the public entities that exist and are still also practicing this particular local method as a mechanism for conflict resolution. This method is believed and obeyed not only because they want to retain its cultural reality, but also because by practising this method, they are able to create a peaceful living in their society. Based on the data in the recent 5 (five) years, the number of conflicts or disputes that occur in society is very minimal. In the year 2009, there was 1 (one) dispute, while in 2010 and 2011, 1 (one) dispute or contentious case between women and men occurred, whereas in 2012 and 2013, there was not a single case that happened.

Based on these data, a conclusion can be made to reflect the low number of conflicts that occur in the community. The community is still strong in incorporating cultural values for an orderliness in the society, and it is interesting to undertake a closer analysis on the phenomenon of various consequences for anyone who violates the rules in the society. The purpose of this study is to explore the cultural aspects that contribute to the orderliness and peace in society, as well as the mechanisms of resolving conflicts which are conducted locally.

\section{Framework}

\subsection{Conceptions of Local Wisdom}

According to Wagiran (2012), local wisdom implies some concept, namely: (1) local wisdom is a long experience, which is applied as an indicator of one's behavior; (2) local wisdom cannot be separated from the environment of its owner; and (3) local wisdom is dynamic, flexible, open, and constantly adapts to its era. In its development, local wisdom is not always rigid as a tool, whereas the concept of local wisdom is bound and in line with the process of human development where it appropriately fits into the context of the socio-cultural background, so that there are always local wisdom in every social reality.

Local wisdom is closely linked to culture, while in practice, culture is comprised of three elements that are the form of idea or ideas, the form of behavior and the form of cultural artifacts. Based on that definition, local wisdom has a very wide dimension, that is the dimension of the idea / concept, the dimension of practices, and the dimension of physical. Local wisdom in the community can be discovered to a greater extend by using all the three elements which cannot be separated or ignored.

According to Wagiran (2012), from the philosophical point of view, local wisdom can be categorized into two aspects, namely: a) the ideas, thoughts, and intellectual capacity which are abstract, covering a wide range of knowledge, views, values and practices of a community, all derived from the previous generation of the community or otherwise obtained by the community in the present, which is not only derived from the previous generation, but also from a variety of experiences in the present, as well as from contacts with people from other cultures and communities. b) local wisdom in the form of concrete objects, or artifactmaterials, which adorn human life, and contains symbolic meaning.

\subsection{Models of Conflict Resolution}

Conflict is often said to be the influence of an inability to meet the changes in society that have happened at a rapid pace, and this often causes the society to resort to conflict resolution method in the form of external intervention from the third party which does not provide any space for people to practice their own settlement mechanism. This type of view on the reality of conflict which is said to be a condition of anomie is a conventional perspective and is still often practiced by policy makers and stakeholders.

There are a number of theoretical models for conflict resolution, and all of them can be categorized broadly into two perspectives, namely: (1) a perspective that tries to get rid of a conflict, usually by using repressive methods. (2) another perspective that sees the reality as having a natural conflict in the community, so that a method is usually taken to accommodate the interests of both parties involved in a conflict. A logical consequence of both these perspectives spawned many variants of a solution of conflicts. 
Conflict resolution can also be seen from the two approaches namely a way of litigation and a way of non-litigation. This study plan will put more emphasis on non-litigation way because the value of local wisdom give more priority to conflict resolution based on familial relations and fair deliberations. Non-litigation process which is done through negotiation mechanism, arbitration and mediation usually makes use of a third party. This approach is often referred to as a model of third party intervention.

Negotiation is a process of negotiation between two or more parties to achieve a mutually acceptable solution. According to Manchester Open Learning (1997), negotiation is a process of reaching consensus in which the interests of each party is reached by means of the co-operative nature. In the practice of conflict resolution, negotiation is not always an acceptable situation which will lead to peace. The phase of the second stage is the use of third-party arbitration mechanisms in which resolution of conflicts is done through the appointment of a third party by the conflicting parties. The final stage is the mediation step to find common interests of all parties. According to Ahmad Gunaryo (2007), it is not something new for conflicting parties to go through a process of mediation in the sense of finding a solution together over a dispute by being led by a mediator in Indonesia.

A similar theoretical approach which was presented by Christoper Moore (2003) shows that the conflict resolution process includes several cases as depicted in the following scheme.

Figure 2 Conflict Resolution Process

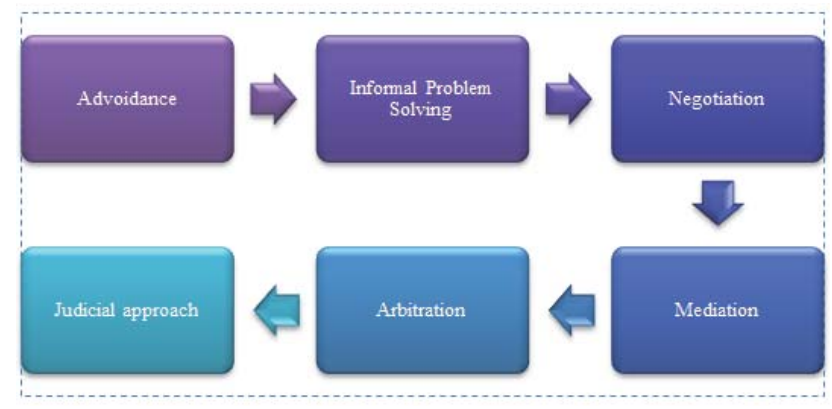

Source: Moore (2003)

Following is an explanation of the process: first; avoidance is a process when the parties involved in the conflict want to avoid each other from getting into conflict resolution. Secondly, there is an informal problem solving, in which the conflicting parties agree to resolve their issues by way of informal solution. The third process is negotiation, which is done between the parties in conflict to find a way out. The fourth process is mediation, whereby the third party is accepted to perform conflict resolution. The fifth process is arbitration, in which the conflicting parties make an effort to find a thirdparty to involve in the conflict resolution. The sixth process is intervention which is performed by authorized institutions, such as in providing legal certainty.

Non-litigation solutions practice is often almost simultaneously held by a mechanism that has evolved in the community. The solution by using the values of local wisdom, that is by giving the opportunity to conduct a dialogue between the parties to the dispute are usually done. By providing a democratic space, the society is given a form chance for a conflict resolution that is constructive and sustainable towards achieving the foundation of harmony in society. This is in line with Habermas's theory of communicative action, in which communication that occurs is to complement and to be understood without any distortion.

This study aims to identify the ideas and values of local wisdom in the process of resolving the conflict mainly through the mechanism of 'Flour Bidding' (Tepung Tawar). Conflict resolution models based on local wisdom are usually similar to the mechanism of third-party intervention. This study emphasizes locally formed ideas which are implemented by the community in building a harmonious life, harmony and peace.

\subsection{Social Cohesion and the Existence of Customary Law}

The community of 'Desa Talang Sejumput ' has a good social relations among its citizens, and they tend to be far away from horizontal conflict. Although the relationship is not as strong or close as in the past, but they have a fairly close 
social contacts. The situation is a manifestation of the value of local wisdom that has long existed and maintained, so that the attitude and behaviors of mutual appreciation, respect, cooperation (gotong royong), and reciprocity, are still being preserved. For example, in the context of mutual assistance during events (gotong royong), the villagers, both men and women alike do still cultivate the habit of giving strong support in mutually helping each other during the charity event without hoping for any compensation. The members of the community always willingly help each other, either in the form of moral or material, such as cooking meals for charity, and also help in lending tools that are needed for the charity event, or helping in preparing the nine basic staples such as rice, sugar, vegetable oil, or chicken. Although this tradition has then become the means to mutually repay back to the the members of village, the villagers are so aware that they are doing are part of the social capital resources that should be preserved and maintained properly.

When examined, the pattern of social relations in Talang Sejumput community can be identified in two different forms, namely in-group social relations and out-group social relations. In-group social relations are shown in the social fabric of the community internally. Based on the findings of the field study, the villagers are seen as having close ties, because the villagers consider each one of the community members as an integral part of the village. This kind of strong social relationships certainly produce a strong solidarity in the society. Then, the harmonious order in the society is at least achieved due to several factors, such as the condition of a homogeneous society, especially from the tribal and religious aspects. In addition, psychologically, rural isolation also provides a strong sense of brotherhood among the villagers. Mutually helping each other and cooperation are examples of a form of social relationship that exists between communities. In out-group social relations, it is observed that the society shows a condition which actually is not a closed society, but it tends to be an open society. In this context, the presence of other people who do not originally come from the same tribe, are not considered as a concern or a source of fear because the villagers assume that all human beings have basically good intentions. They showed a positive bias through displaying their enthusiastic attitude by welcoming visiting outsiders and treating them well.

The community of Talang Sejumput is one of the public entities that is still clinging strongly to the customary order in the management of their local community. Local values are still held in high esteem and regarded as one of the sacred buildings that should be maintained and adhered to. Based on the information derived from a religious leader, Husni (aged 60), the laws and customs have always come together and never separated in the community. The emergence of customary law is due to the order of the rules to behave in the society. In accordance to Marsin's research report (aged 80), he said, as a public figure, that:

\footnotetext{
"... given the example that one person who is not cultured has just come to this province, but he gives no greeting, so this person is considered as reckless or not cultured. So, customary law should be coupled with customary order..." (Marsin, aged: 80, Friday 2013)
}

According to the informants, there is always an indirect rule in the community that encompasses the ways how people were to act and behave, so that the custom will produce some consequences for any violations of the custom through customary law. Based on the statements from several informants, in the society there are always courtesy and manners. The standard is a measurement to assess whether a person is regarded as cultured or not cultured.

Customary law can be interpreted as the rules in a society that is produced through the local wisdom which is used by the people to address various issues that arise in the community. They are initially based on a standard ideal that is good or bad. This condition is the initial foundation or philosophical basis for the birth of a law or rules and regulation in the community. In this scenario, it could be argued that customary law was born naturally from the process and experience of the community itself. In other perspective, based on findings through in-depth interviews with an informant "Jurai Tue" or a traditional leader, it is declared that the source of customary law was clearly born from the members of the society but they get the formal rule of law through the Torrent of Light Law (Undang-Undang Simbur Cahaya) which is often referred to as a customary law .

The source of law is the basis for every decision on the custom in the community, but although these regulations are already recorded in written form, it will still be interpreted contextually by the community. This is because sometimes there is rationalization to be made or other logical considerations to refer to before a customary law is determined to be used. This flexible situation shows that people in the community understand the philosophical basis of a customary law as they believe it to be one of the most humanist law to be applied in the community.

The transformation of any customary law is done through traditional leader " Jurai Tue ". Based on the interview with the head of customs, knowledge of customary law is handed down or socialized and internalized from an early age by parents. Moreover, according to the informants about the Jurai Tue, that there is someone who is considered as a blessed one who leads or a number of Jurai Tue in Sepanjang Sungai Batang Hari Sembilan, precisely in the Desa 
Endikat. Since they are still young, potential successors of the Jurai Tue is sent by his parents to participate in any activity at the place of the leaders. On the night of the 14th of each month, all Jurai Tue comes to the charity event which is held as an opportunity for communication between fellow Jurai Tue and and the leader of Jurai tue.

Although there are records or books of customary law on the "Torrent of Lights Law" (Hukum Simbur Cahaya) which is held directly by the traditional leaders / Jurai Tue, it was observed that in the practice and application, the process of socialization and contextual understanding of the problem and the resolution process is more dominant as an opportunity for transformation of knowledge rather than textual understanding of the book.

The customary law which is practiced by the local community is not separated from the indigenous doctrine which promotes the application and the teachings of the prevailing custom. In addition, there is a correlation between the customary law and religious law, especially Islam, in strengthening the position of customary law which is considered as a means to enforce religious rules. However, there is no assurance that a customary law would always be passed down to the next generation.

\subsection{The application of customary law}

In practice, the application of the customary law which is made by the people is not separable from the role of the application of the custom therein. Based on the collected data from the field study, in the matter of customs, there are some people who holds an important role and function in the society to apply the customs, namely "Jurai Tue", "JungkuJungku", and important figures in the community. All the applicators of the customs have an important role in carrying out the customs regulations. To clarify the customary leadership hierarchy, the Talam Sejumput Community highlighted the following schema:

Figure 3: The Structural Rule of the Customary Law of the Community in Talang Sejumput

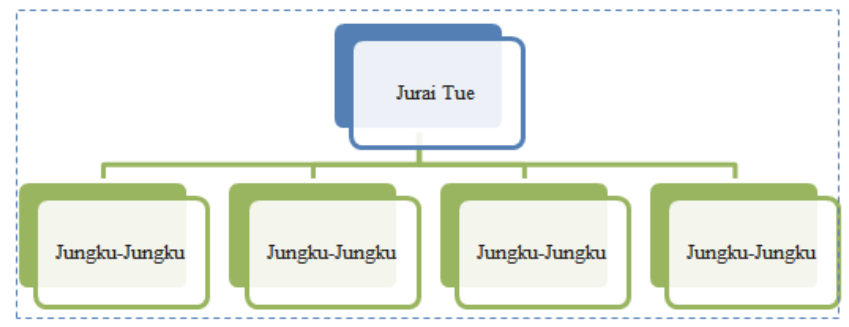

Source: Alfitri, 2011

Jurai Tue is the highest tradition of leadership and is acknowledged by all components of the community, organizing various issues relating to customs. Jungku-Jungku, the Jurai Tue's assistants in the performance of the custom. Specifically, the following discussion will explain both of these positions.

\subsection{Jurai Tue (The Leader of the Customary Law)}

Jurai Tue is a custom head to the authority of customary rules generation. In South Sumatra province, especially in certain specific province such as Kabupaten Muara Enin, Lahat, and Pagaralam, the term Jurai Tue is widely used and known among the community, especially those in rural provinces. But there are differences based on the lineage, such as in Pagaralam, Jurai Tue should be passed down to the oldest son, while in Marga Gumay Lahat, including areas in Talang Sejumput, the position is given to the last son. The youngest son is the heir and would inherit the position of Jurai Tue . If the Jurai Tue did not have a son, then the position of Jurai Tue, would be passed down to to the youngest son of the Jurai Tue's brother.

Jurai Tue is considered the same as the formal head of the government, as he has a role to manage the society in accordance with the customary law. But Jurai Tue has a big role and responsibility that needs to be carried out compared to a formal government leader. Jurai Tue's role is to organize and manage the society in order to maintain harmony and sustainability therein. Knowledge is gained by Jurai Tue through own experience in the process of socialization that is passde down from a generation after generation. The internalization of values has been instilled by his predecessor at a 
very early age, in addition to the processes and mechanisms of socialization done informally through family environment, and the people in the community.

Each problem which is handled by Jurai Tue is mostly carried out in the house, so this will indirectly provide learning opportunities to the prospective successor in the descendent about the process and the traditional mechanisms that are handled by Jurai Tue. The transfer of local values from a Jurai Tue to his predecessor is also done when the potential successor enter adulthood, whereby the successor is brought to traditional events which are held in Endikat. The process of transformation of local values by JJurai TTue predecessor, is also done when a potential successor has entered adulthood, to bring their children to the traditional events held in Endikat. So this process is handed down to the successor who will hold the status of Jurai Tue in the future; however, the knowledge transfer is usually delivered directly by Jurai Tue to the sucessor when he has become an adult. The Jurai Tue will be automatically replaced when he dies or can no longer actively carry out his role.

\subsection{Jungku-Jungku/Aling-Aling (The application of customary law)}

The traditional chiefs who carry out their roles and duties in order to manage the community are facilitated by Jungku Jungku. In some other areas, for example in the custom leadership in the province of Pagaralam, this position is known by the name Jungut Jurai, but the meaning remains the same which is the assistant of the Jurai Tue. Jungku-Jungku is the person who implements customary law, and his position is obtained in accordance with hereditary law. His duty is to assist in the duties of the head of customs. There are four Jungku-Jungku with different roles.

The first Jungku-Jungku has a role for peacekeeping, working to help Jurai Tue in managing or monitoring security and peace in the country concerning various issues relating to people in general and in relation to internal and external parties who are from the outside of the country. The second Jungku-Jungku's role is to ensure a hygienic environment in the village and will be in charge when a cleaning procession is made to clean up the village. Cleanliness means a comprehensive coverage of not only physical hygiene such as cleaning the rivers and the environment) but also concerning clearing the symbolic aspects used by the people in the village in order to defend the community through rituals therein. The third Jungku-Jungku observes his duty in doing charity (Sedekahan) and to implement his custom duty to assist in doing charitable ceremonies or events. The fourth Jungku-Jungku acts as a messenger and has to implement his customary duties to come during the events in the evening which are relating to the fourteen supernatural related problems. Aside from that, Jungku-Jungku who is the mesenger has to help to complete a variety of equipment for customs purposes eg coconut, rice, yellow and white chicken. Although the all four Jungku-Jungku have their own specific duties, they are often instructed to carry out other type of work after obtaining an order from the Jurai Tue.

There is a high dependency to the traditional leaders because the authority possessed by Jurai Tue is much greater compared to that of Jungku-Jungku. Adherence to Jurai Tue is a rule that can not be avoided by Jungku-Jungku because in each case that is requested by Jurai Tue, Jungku-Jungku will always be ready to implement them. JungkuJungku, being responsible to follow any order given by Jurai Tue, also carry out their duties as a formal partner with local governments. Even so, in the hierarchy, Jungku-Jungku is equivalent to the head of the village, while in the performance of their duties, they are fully responsible for any orders from Jurai Tue.

\section{Research Objectives}

The purpose of this study is to explore the cultural aspects that contribute to the orderliness and peace in society, as well as the mechanisms of resolving conflicts in the form of conflict resolution models in the society which relies on the local wisdom. This study found that the local community conflict resolution model can be used as a reference in resolving conflicts in communities that have different local values.

It was decided that the best method to adopt for this investigation in recording and analyzing this subject was to use a qualitative approach. The purpose of a qualitative approach is to come up with systematic, factual and accurate descriptions, maps, pictures, or drawings, in revealing the attributes and relationships between the phenomena under investigation. Data collection was made with the in-depth interviews with several informants of the study. The informants of this study were the chief of the village, the heads of customs, public figures, religious figures, and jungku-jungku. Observations were carried out to see how people resolve conflicts through customary rituals. The study also used Focus Group Discussion technique to check the data collected from the informants. Data were analyzed by using coding process by three researchers through discussions in order to summarize the findings and to come up with the conclusions of the study. Application of the model was agreed upon by the members of experts after going through a discussion. 


\section{Result and Discussion}

\subsection{Violations Cases of the Customary Law}

Based on the findings of the study, cases that violates the customary law that are often found in the community are at least addressed through the process of customary solutions. There are some cases for example the rules of relationship between men and women, relationship conflicts or violence. Everything concerning customs are managed and handled by the head of customs. A few cases including the ones that are regarded as violating the customs are highlighted in table 1 below:

Table 1: Violations Cases of the Customary Law and the Resolutions

\begin{tabular}{clccc}
\hline No & Case & Victim & Perpetrator & Solution \\
\hline \multirow{2}{*}{$\mathbf{1}$} & $\begin{array}{l}\text { Male and Female } \\
\text { Relationship }\end{array}$ & & & \\
\hline a) & Harrassment of the Female / Touching Hands (Nabigh Betine) & Female & Male & Penalty \\
\hline b) & Men spying girls in shower (Taungan Macan) & Female & Male & Penalty \\
\hline c) & Touching Mouth (Cempale Mulut) & Female & Male & Penalty \\
\hline d) & Preceding the Law or Adultery (Dahului Hukum or Zina) & Male and Female & Penalty and Separated \\
\hline $\mathbf{2}$ & Dispute and Fight cases & & \\
\hline a) & Inheritance dispute & & Discussion for consensus \\
\hline b) & Fight & & Penalty \\
\hline c) & Murder & & Penalty \\
\hline
\end{tabular}

Examples of such cases are a glimpse of the problems into the realm of custom which are settled through customary law. The descriptions of various cases described above are explained in the following paragraphs:

\subsection{Case of Male and Female Relationship}

The customary rules of Talang Sejemput society provide a substantial protection for women. The findings provide insights that figures of women as an entity should be respected and appreciated that customary rules are derived to enforce justice for women. In the mixing of men and women, there are some limitations of customary norms in it, and when violated, will be affected by the sanctions of the customary law.

\subsubsection{Harassment of the Female}

The term nabigh betine is used to describe an action that includes a harassment done by a man on a woman. According to the testimony given by an informant who is a traditional leader, the offense of nabigh betine is when a man, as a perpetrator, touches the hand, or any parts of a woman's body and as victims, they are displeased with the offense. This type of harassment has different levels in terms of violation and sanctions. In a case when the woman sheds some blood or is injured, the man would directly get the heaviest sanction that is a penalty to clean the whole countryside by slaughtering one goat.

The women in the community of Talang Sejemput are regarded highly and very much appreciated. This can be seen from the customary law that gives special protection to women. The Book of Law Kitab Undang-Undang Simbur Cahaya specifically regulates the relationship of women and men and is found in the first chapter namely Rules for Single Men and Women and Marriage, which contains 32 articles. In 18-24 the book describes in detail the actions that can be categorized as nabigh betine. For example, chapter 21 outlines the following:

"If a man holds a single girl or a widow then hug her " meragang gawe ". Then, he is fined 12 ringgit, if a woman complains as being harrassed and 6 ringgit is returned to the women on the basis of "tekap malu", and 6 ringgit is returned on the basis of being harrassed (Article 21; Chapter 1)

The explanation of indigenous witnesses based on the law, that cases of abuse or harrassment against women must be logged as a regional customary law in the resolution process. Having exercising justice mechanisms through customary law, a sanction of a fine of 12 dollars is paid to the victim by 6 dollars to restore the good name, and 6 dollars 
as a cost for the local custom fees and custom agent.

This rule is understood in a contextual way by the people in the society, as how it is acknowledged by the term nabigh betine in the community, which is an interpretation on the written rules and regulations. As a sanction, it is more known as cempale tangan because it is an action done by the petpetrator with his hand. The rules is still practised in the community til date.

\section{3 'Taungan Macan'}

Based on the data collection, the term "taungan macan" is a violation of customary law when a mn spies a girl in a shower or urinating. The sanctions "pendawean" or a penalty money is around 3 million today. But in the early days, the money is calculated by dollars, one dollar is worth the price of one buffalo. The term "taungan macan" is described in the Book of Law Kitab Undang-Undang Simbur Cahaya and is still firmly held by the society, namely in the article 29 as follows:

Whoever is caught spying a woman bathing and doing it in a hiding place, then he is fined four dollars. (Chapter 1. Article 29).

Based on the law, which is also arranged on custom sanctions due spying on woman who is taking a bath, the perpetrator will be fined with four dollars, or the equivalent of four buffaloes, which is the value at the time. But for now the fine has been adapted to the socio-economic conditions of society. The sanctions given are not only in term of a fine but also social sanctions such as a lesson to learn and social control that is valuable to the society. To deter the occurrence of such actions in the community, places of shower for males and females are separated.

\subsection{Touching Mouth (Cempale Mulut)}

The term Touching Mouth (cempale mouth) is a violation of customary law that is done by someone who commits a libel or slander. According to an informant Nirwan (aged 40), the term does cempale mulut is done through verbal act, for example defamation, such as speaking ill of others, while cempale tangan is an act which is done by hand. According to all informants, there is no objection in revealing the meaning and usage of both terms which appear frequently in interviews with the community. The following is the informants' information about the violation of cempale mulut:

[... at the time a person says something as a libel or slander, he must also do the Flour Bidding ceremony or 'tepung tawar', and the term is cempale mouth. The sanction for "cempale mulut' is by paying 3 dollars] (Interview with Isnan, aged 60)

The evidence presented by multiple informants about the case is about some customs violations called cempale tangan and cempale mulut. The knowledge is gained as a result of socialization and internalization of local values in the community. The terms which are understood by the public as in the case with the rules set forth in the Book of Law Kitab Undang-Undang Simbur Cahaya, such as the following:

[if someone curses or says something mean towards the wife or daughter of other people, or mention something that is not appropriate or should not be stated, it is called "cempala mulut", and he is sentenced to a fine from 2 to 12 dollars at the discretion of the meeting] (Chapter 5 Article 19)

The Book of Law Kitab Undang-Undang Simbur Cahaya explains that the act of defamation is an act that violates the custom. A perpetrator must be sanctioned after the custom of justice is committed by the head of customs and jungku-jungku. A customary sanction of a fine in is accordance with the act of the lowest rates of two (2) dollars and up to 12 dollars.

\subsection{Preceding the Law or Adultery}

Based on the findings, cases of violations of the custom called "Preceding the Law" or adultery has happened several times in the provincial village. Almost all the cases were solved through custom solutions. This is because only a custom mechanism has detailed rules on these cases. The law is an application of the principles of customary law based on the legal book of Kitab Undang-Undang Simbur Cahaya. 
In the book, the rule of law for the act of preceding the law or committing adultery is found in Chapter 1 Articles 8 , 9, 10 and 11. Each chapter explains the act according to the situation and condition. For example, article 8 outlines the following:

\begin{abstract}
"If the bachelor and the single girl have a relation out of wedlock, and she gets pregnant, then the bachelor has to pay a fine of 12 dollars and then they must then also be wedded as outlined in the custom but do not need to pay for maintenance fee for other than physical".
\end{abstract}

"From a fine of 12 dollars, if they are in a village, to be returned to the villagers 10 dollars and 2 dollars to the petperators and if at a place with walls with 6 ringgit returned to the owner, 4 ringgit to the heads of the village and 2 ringgit to the petperators". [Chapter 1. Article 8]

In practice, customary law is used as a basis for determining the rules in a society. Based on the analysis of the data retrieved from the public, the most recognizable term to describe the sanctions for the act of adultery is "tekebau" and "tekambing". Usually the petpetrator was forced to endure social and psychological sanctions because he or she is stereotyped by the society as a person who pollute the village.

\title{
4.6 Dispute and Fight cases
}

In customary law, disputes and violence are also included within the realm of the conflict resolution through traditional mechanisms. The law of Simbur Cahaya as one of the mechanisms for the management of the local community, as well as organization of such cases as detailed in Chapter of Customary Law, articles 13, 14, 15, 16 and 17. For example Article 14 mentions the following:

\begin{abstract}
"If people are fighting or exchanging blows with their hands or sticks in the house or on the site of the village, whether the effect is swelling or no swelling, they are fined 2 dollars to 6 dollars, and the one who is wrong should give out some flour that costs from 1 to 4 dollars to the person who is injured or gets swollen".
\end{abstract}

While article 17 mentions the following:

"If people fight to the extend that his enemy becomes disable, or in other words, missing eyes, ears, legs, or hands and has lost his natural ability, the perpetrator is punished and will have to pay 20 ringgit to the handicapped.

The traditional rules which are written in The law of Simbur Cahaya have become the foundation for people to resolve disputes or conflicts within the community. In practice, the actualization of such a rule is always adjusted to the social setting of the local community. This reality shows that people understand the customary law contextually and not textually. This is one reason why the common law and conflict resolution mechanisms based on local values still exist until today.

\subsection{Conflict Resolution Model Based on Local Values}

Completion and conflict management in the local community is the authority of traditional leaders "Jurai Tue" who is assisted by indigenous applicators of the law, Jungku-Jungku. The last couple of cases that have been experienced by the local community are illustrated in the following diagram.

Table 2: Case of conflicts in Talang Sejemput society in five years

\begin{tabular}{lccccc}
\hline \multirow{2}{*}{ Type of cases } & \multicolumn{5}{c}{ Total of cases } \\
\cline { 2 - 6 } & 2009 & 2010 & 2011 & 2012 & 2013 \\
\hline Conflicts between Female and Male & 0 & 1 & 1 & 0 & 0 \\
\hline Fighting & 1 & 0 & 0 & 0 & 0 \\
\hline Murder & 0 & 0 & 0 & 0 & 0 \\
\hline Total & 1 & 1 & 1 & 0 & 0 \\
\hline
\end{tabular}

Based on the table above, the quantity of the total number of conflicts or disputes in the community is very low. Some conflicts cases are still emerging, especially in 2009 when there was a fight case, and in 2010 and 2011 male and female 
differences; however, in 2012 and 2013 there was no conflict in the society because of the practice of the customary law.

These data raises basic questions such as why the reality of conflict in the community was minimal. The explanation is that the initial hypothesis that common law and the sanctions in it that are used as conflict resolution, act as a deterrent for the perpetrators and provide lessons for the community. To analyze these hypotheses, the model of conflict resolution as done by custom authorities namely Jurai Tue is explained in the following design:

Figure 4. The Scheme of Conflict Resolution Model on the Basis of Flour Bidding (Tepung Tawar)

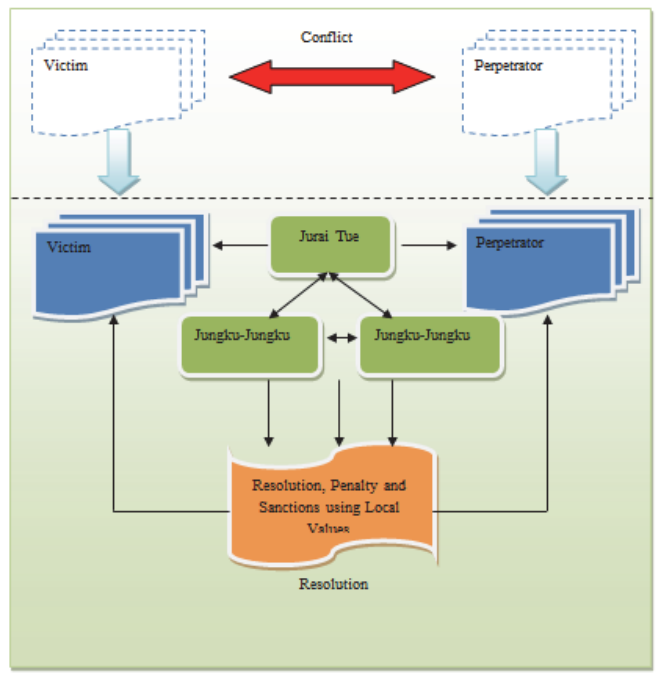

Source : Alfitri, 2013

The above scheme shows a conflict resolution model that is performed by a custom head with the implementator. Starting from a case between two parties who are disputing, in a conflict, and misunderstanding. A conflict can be violent or symbolic such as defamation and so forth. The problem is known to the head of customs, through the reports of perpetrator or the victim, or a direct information from the community. Traditional chiefs with authority are to call on both sides to hear from both sides about what has happened. The process of calling both sides is done separately, started by calling the victim through jungku-jungku, in order to analyse the case or to ask the victim to clarify the whole problem. Once this is done, the head of customs through jungku-jungku call the perpetrator, to ask about the things that have happened. Then, clarification are made about the information given by the victim.

In the process of this clarification, the results of which will be dependent on the wisdom and sharpness of mind of custom leaders. To prove the validity of the information, the customs head usually uses symbolic tools for example the Koran to see the honesty of the victim or perpetrator. Besides making direct clarification from both sides, the custom head usually also calls upon any witness in the matter. However, the witness is also cross-checked in order to ensure truthful clarifications and information about the case. Usually the custom head does not immediately give a sentence or a sanction to the guilty because there are considerations in every decision made.

Information from both parties are carefully investigated and explored by the traditional leader who is assisted by the custom implementator. Before deciding on a verdict, the head of the customs as a mediator between the two parties to the dispute will offer a solution that is acceptable by both parties. Based on the information submitted by the head of customs that, in resolving conflicts, deliberation and reconciliation are given priority. For example, the traditional leader will put an effort to reconcile the two sides to be able to forgive each other and forget all the mistakes they did. These deals are often done before making any final decision of the matter.

The principle of peacefulness that underlies any conflict resolution performed by the head of customs is as follows: "Yang besak haruse dikecikkah, yang kecik haruse diabiskah" (A big problem is supposed to be reduced, while a small problem is supposed to be ended/removed). The local phrase is the basis for every decision, or a part and parcel of the consideration of the decision made by the head of customs. Whether it is a serious conflict, such as a murder case, the 
principle of peace is always chosen in order to find the best solution. However, according to the head of customs, if the case cannot be reconciled through the peaceful mechanism, both parties should agree to go for a final decision of the matter which involves sanctions or penalties.

\section{Conclusion}

Conflict resolution through the local wisdom in Talang Sejumput community is able to maintain a peaceful situation in the community on an ongoing basis. This condition is an aspect of values transformation that still exists from generation to generation as a part of an elite network of formal conflict resolution mechanisms. The application of this conflict resolution model in the rural traditional communities can be used as a basis of conflicts resolution in different cultures and communities by adapting its structure to the local community and cultural conditions.

Overall, the initiative that combines elements of traditional community values, norms and local customs in resolving social conflict is a unique method. This is because the diversity of attitudes and practices of life in rural communities has been treated carefully in the construction of harmonious conflict resolution strategies. Several models of conflict resolution in this research revealed the importance of local values and culture of each tribe in the maintenance of harmony in their society. This is a highly valuable cultural treasure.

However, the extent to which the technological developments will affect the cultural practices is still not unclear. This is because the exposure to electronic media among rural adolescents is capable to give an impact on the use of traditional practices. Thus, further studies on these questions are deemed necessary.

\section{References}

Abolmaali, K. , Keivan, L. \& Ajilchi, B. (2014). The Prediction of Social Problem-Solving Skills Based on Birth Order and Attachment Styles. Advances in Applied Sociology, 4, 15-19. doi: 10.4236/aasoci.2014.41003.

Ahmad Gunaryo. (2007). Mediasi dan Resolusi Konflik di Indonesia, dari Konflik Agama Hingga Mediasi Peradilan. WCM: Semarang.

Alfitri. (2011). Community Development- Teori dan Aplikasi. Yogjakarta: Pustaka Pelajar

Alo Liliweri. (2009). Prasangka dan Konflik, Komunikasi Lintas Budaya Masyarakat Multikultur. Yogyakarta: LKIS

Celina Del Felice. (2008). Youth Criminality and Urban Social Conflict in the City of Rosario, Argentina, International Journal of Conflict and Violence, Vol 2, Iss 1, 72-97

Chistopher Moore. (2003). The Mediation Process: Practical Strategies for Resolving Conflict. San Fransisco:Jossey Bass

Manchester Open Learning. (1997), Mengendalikan Konflik dan Negosiasi.PT. Gramedia Pustaka Utama: Jakarta

Novri Susan .(2009). Sosiologi Konflik dan Isu-Isu Konflik Kontemporer. Kencana Media Group: Jakarta.

Suharsimi Arikunto. (1999). Prosedur Kajian : Suatu Pendekatan Praktek. PT. Renika Cipta: Jakarta

Undang-undang Simbur Cahaya. 1922. Indonesia

Wagiran (2012). Character Development Based on Local Wisdom (Pengembangan Karakter Berbasis Kearifan Lokal), Hamemayu Hayuning Bawana, Jurnal Pendidikan Karakter, Edisi Februari , 329-339. 